\title{
An Analysis on the Influencing Factors of the World Food Price
}

\author{
Fang $\operatorname{Min}^{1}$ \\ ${ }^{1}$ Shandong Zibo Experimental High School, 255000, Zibo, Shandong, China \\ Correspondence: Fang Min, Shandong Zibo Experimental High School, 255000,Zibo, Shandong, China
}

Received: March 25, 2019

Accepted: July 5, 2019

Available online: July 26, 2019

doi:10.11114/afa.v5i2.4412

URL: https://doi.org/10.11114/afa.v5i2.4412

\begin{abstract}
The paper analyzes influencing factors of the world food price by using the data from 1964 to 2013. There is cointegration relationship between the world food price, world agricultural productivity, world food production, food consumption, food inventory, world oil prices, and the exchange rate of dollar. The world agricultural productivity, world food production and the exchange rate of dollar have significantly negative effect on the world food price. The world food consumption has significantly positive impact on the word food price. The impact of the world food stock and the world crude oil price on world food prices is not statistically significant. The elasticity of world food production on the world food price is less than the elasticity of world food consumption. To improve the agricultural productivity, increase food production is the key measure to stabilize the world food prices.
\end{abstract}

Keywords: world food price, influencing factors, agricultural productivity, effective exchange rate of dollar

\section{Introduction}

Recent years have witnessed great fluctuations upon grain price around the world. During 2007-2008, the sharp uprise in world grain price has given rise to the food security problems in most developing countries of Asia, Africa and Latin America, in the wake of which, serious conflicts and political instability emerged in some of those countries. In 2009-2010, the world grain price fell back, which lasted for two years. And in 2011, the world began a new round of price increase, though seasoned with fluctuations; the price was kept at a high level. Food price volatility, especially the high fluctuations, is the main factor affecting food security, whose influences were more serious upon people living in poverty. According to (FAO) in 2009, food security means all the people around the world can get enough, safe and nutritious food all the time, to satisfy the need to keep a positive and healthy diet and cater to the their food preference. That is to say, to ensure food security needs not only sufficient food supply, but also enough capability to obtain food. The rising food price and frequent fluctuations would obviously increase the cost of people to buy food, because food is a necessity, the price elasticity of its demand is extremely low, so when the food prices rise, people will not reduce its consumption. Thus, the influences of food price fluctuations are more severe to people living in poverty. Therefore, to master the laws of price changing and take effective measures in advance, are of great significance to ensure food security. To make that happen, people should first put the formation of world food price, the main factors affecting the price and how those factors functioning at top priority. In recent years, there have been a large number of domestic and foreign scholars began to focus on world food price volatility and the factors influencing the formation of world food prices.

The close relationship between futures price and spot price of wheat, corn and soybean in Chicago Board of Trade has been verified by the approach of linear regression (Bigman et al, 1983). The price of agriculture products were relatively lower in the 1960s, in the 70s and the first half of 80s, the price was much higher, and in the $80 \mathrm{~s}$ and the second half of 90s, the price fell back, but still higher than that in the 60s (Gilbert, 2006). An analysis on the price fluctuations on the international level has been made based on the monthly data of corn, wheat, rice and soybean from 2002 to 2009 (Cooke \& Robles, 2009). The pattern of world food price fluctuations from 2007 to 2009 has been studied by using the model of GARCH $(1,1)$, and concluded that the food price witnessed high volatility in those three years (Gilbert \& Morgan, 2010). In the past ten years, the food price had reached a new high, then declined and came the great price fluctuations. Except the rice, the price fluctuations of other grains were within historical experience, and there was no strong evidence showing that the price fluctuations had experienced increase in the broad sense (Gilbert, 2011). 
The impacts of natural disasters such as weather, etc are widely considered to be the main factors that were conducive to food price volatility. However, the impacts of demand, which were especially true income andpolicies constituted its main factors as well (Christiaensen, 2009; Gilbert, 2010). The food price volatility level was directly or indirectly influenced by macro-economic policy, especially the monetary policy, such as interest rates, inflation and exchange rate (Lapp \& Smith, 1993; Karali \& Power, 2013). The short-term speculationwas a critical variable to explain the fluctuations in the price of food (Pindyck, 1994). Due to the subsidies and government support for the biological energy industry, the market demand for corn and soybean doubled, causing abnormal fluctuations of food price (Tyner \& Taheripour, 2008). Global energy volatility and the expansion and contraction of biofuels industry, market speculation and trade policies adopted by some countries, brought about the sharp fluctuations of world food price from 2006 to 2009 (Huang Jikun, 2009). World food price volatility and grain output, grain consumption and grain stocks were closely associated with each other (Wang Wenbin \& Dai Jinping, 2009). World food price fluctuations resulted mainly from financial speculation in the futures market (Cooke \& Robles, 2009). Therapid growth of China and other Asian economies contributed to the high world food prices (Gilbert, 2010). Whether in a short-term or long-term, world oil prices and the dollar real effective exchange rate played a significant role in the fluctuations agricultural prices (Nazlioglu \& Soytas, 2011). one striking feature in recent world price volatility is the synchrony between energy market and grain market (Baffes, 2011). As for the relationship between food storage and food price, that inventory effectively intensified price volatility (Mitra \& Boussard, 2012).

In summary, previous scholars divided factors affecting world price into two levels, one is on food level, and the other is on monetary and financial level. Food supply, food demand, food storage and biofuels, etc can be classified into the first level. International capital flows, the dollar exchange rate and other factors can be classified into the second level. The previous studies, tended to focus on a particular aspect, rather than analyze which aspect functions better by the combination of both aspects. And the analysis mainly concentrated on the price of a certain kind of grain, lacking proper analysis of world food price and comparisons between different crops. This paper intends to make a systematic analysis on the whole international grain price and the factors affecting various kinds of crops, from the perspective of food supply, food demand, international oil price, dollar exchange rate, and international capital flows. The food in this paper is in its narrow sense, namely, the international grain, including rice, wheat, corn, barley, rye, oats, sorghum, millet and grain variety, not exactly the same with the grain in our country, for food in China comprises bean and tomato. But in China's grain composition, crop yields accounts for the largest proportion. According to the Chinese statistical yearbook data of grain production in 2013 crop yields accounted for $91.8 \%$ of total grain output.And crop yields is the main factor affecting food security as well.

\section{Influencing Factors}

Price is the value of currency performance and fluctuates around the value, and value is the condensation of undifferentiated human labor in the goods, this is the basic principle of Marxist political economics.Accordingly the world food pricecan be believed to be determined by the value of the world food.Commodity value measurement is based on the social necessary labor time in the condensation in the commodity, the longer the social necessary labor time, the higher value.Producing goods used by the social necessary labor time is inversely proportional to labor productivity, labor productivity is higher, the less likely the necessary labor time, the value of the goods will be low.Due to the progress of science and technology, the labor productivity has improved, so it is also true in the field of food production.Generally using the total factor productivity (TFP) to represent the technology advancement, and the agricultural technology progress are reflected by the changes in the agricultural productivity, as is shown in figure 1, from 1961-2013, world agricultural productivity continued to grow, so the value contained in the food was in declining in the long run.

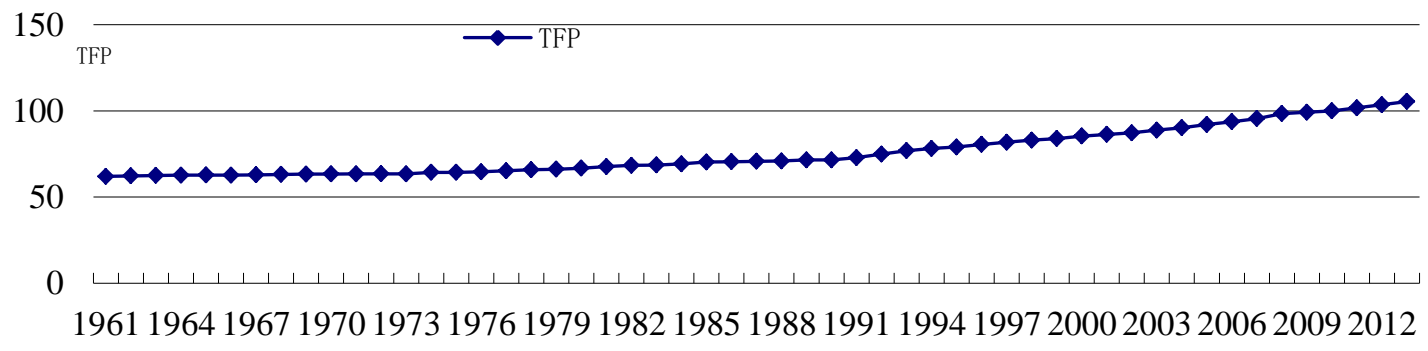

Figure 1. The world agricultural productivity from 1961 to $2013^{1}$

\footnotetext{
${ }^{1}$ The above data are the world's agricultural productivity index, with 2010 as the base year, from the US Department of Agriculture database
} 
Based on the equilibrium of supply and demand theory proposed by Marshall, world food prices should be decided jointly by the international food supply and demand.Supply exceeds demand, prices will fall;Demand is greater than supply, prices will rise; when there is excessive demand, prices will rise; otherwise, it will fall. Within a period of time (usually one year) of the world's food supply is mainly composed of two parts, one is the current production, and the other is the beginning balance of inventory, but production is fundamental. Net imports of grain is also an important source of a country's food supply, but for the whole world, a country's net import of food is food net exports of other countries, thus, in the calculation of the world's food supply, they counteract each other, so don't need to be included in the world's food supply.Grain stocks come from food production, and the changing of food stocks mainly depends on the difference between the current food production and consumption. Current food production is lower than the current food consumption, grain prices will rise, but the initial inventory could suppress the rising;Current food production is higher than the current food consumption, grain prices will decline, and the inventory can reduce declining as well, so inventory have played an important role in stabilize prices.Figure 2 shows the change of world cereal production, consumption, and inventories, from which you can see, the world grain production and consumption has a long-term growth trend, although in some years there exist price fluctuations. Through the change of inventory, we can seethe gap between each period of grain output and consumption, and the gap between them has gone through ups and downs.

By comparing with grain price index released by the United Nations food and agriculture organization, we cam found that around 2000, when the world grain stocks was higher, world grain price index is lower, and from 2006 to 2008 , when the world grain stocks lower, world grain prices are higher.Thus a hypothesis can be concluded that there should be a negative correlation between the current world food production and the current world food prices and the current world food stocks; there should be a positivecorrelation between the current world food production and the current world food consumption.

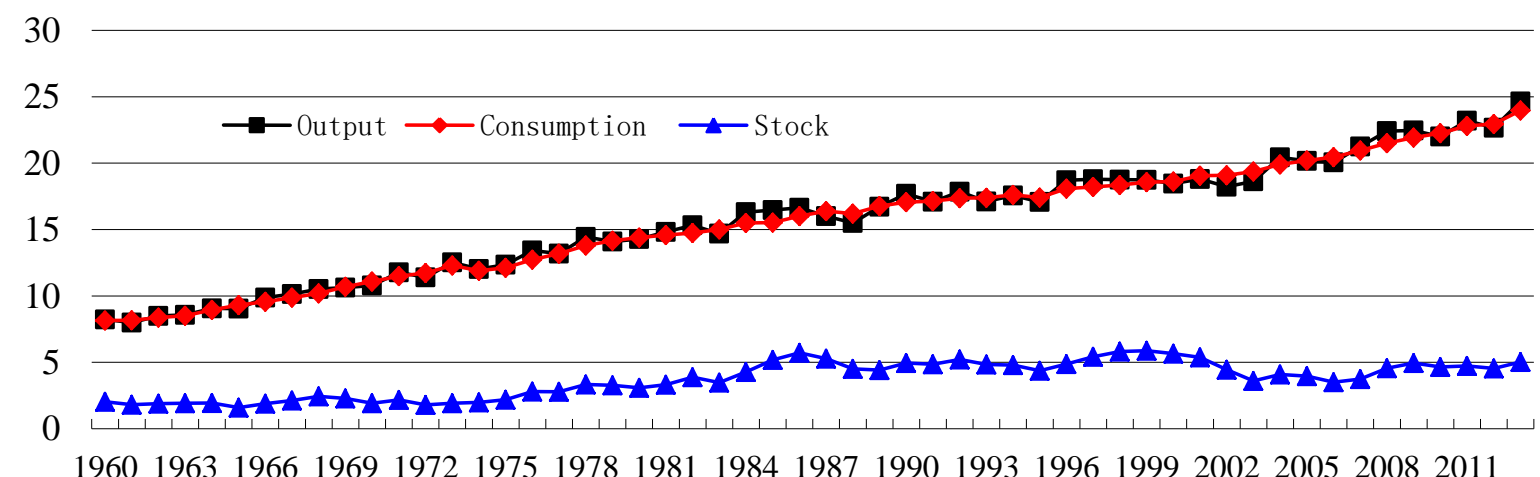

196019631966196919721975197819811984198719901993199619992002200520082011

Figure 2. 1964--2013 world cereal production, consumption and stocks (One hundred million tons) ${ }^{2}$

World energy price is closely related to food price. For food production, energy intensive is one phase that must be practiced. Oil is the main energy employed in the production of food; therefore, the energy price applied in analysis refers to the price of crude oil. The energy price exerts influences upon food price, which is mainly achieved by the channel of food production investment. For instance, higher energy price increases the cost of food production machinery operation, fertilizer and transportation. The energy price can also exert its influences upon food price by virtue of bioenergy. Bioenergy refers primarily to the biological diesel oil and fuel ethanol extracted from crops such as corn, sorghum and soybean. That kind of energy can be a substitute for oil. Therefore, when oil prices rise, the biological energy as its substitute will increase, which will produce the required food products in the production of biofuels needs, leading to rising food prices. Figure 3 shows the world grain prices over a scatter diagram of the world's oil price change, showed significant positive linear relationship.From those above, it can be seen the energy price has positive influence upon world food price.

\footnotetext{
${ }^{2}$ Figure cereals including rice, wheat, corn, barley, rye, oats, sorghum, millet and grains and other nine categories of food crops, Inventory means beginning stocks.Data from the US Department of Agriculture (http://www.usda.gov) database.
} 


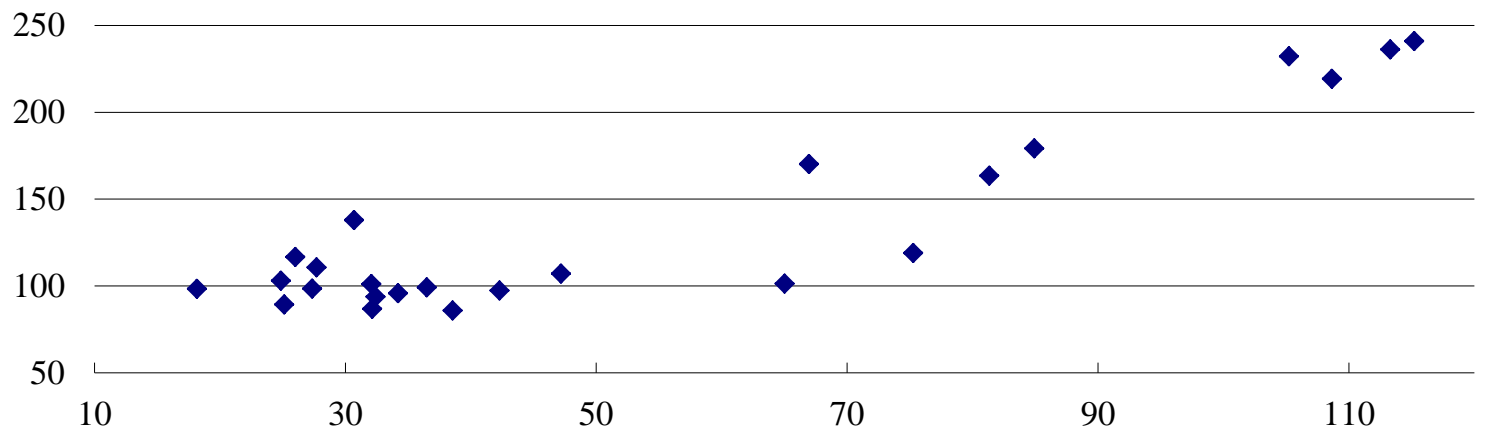

Figure 3. 1990--2013 world oil prices and the world prices of cereals scatter plot $^{3}$

In the world food trade, a world food price isgenerally expressed in dollars, so the US dollar will naturally affect the world food prices.The current world food prices are high, which is affected by the devaluation of the dollar.The devaluation and appreciation of the dollar can be measured by the dollar's effective exchange rate.Effective exchange rate is a kind of a variable as the weighted average of the exchange rate index weight calculation. Effective exchange rate can be divided into nominal and real effective exchange rate; nominal effective exchange rate is used to measure a country's currency relative to other a set of weighted average of the currency, the real effective exchange rate is adjusting for price changes, which strips out the effective exchange rate after inflation.Nominal effective exchange rate should be used in this paper, because the price is a monetary phenomenon, the lower the value the higher the price, so there is no need to eliminate inflation.According to the bank for international settlements data,The US dollar would continue to depreciate since 2001, and with the devaluation of the dollar, the world grain prices began to rise, figure 4 shows the grain price index and the dollar's nominal effective exchange rate changes in the reverse relationship.

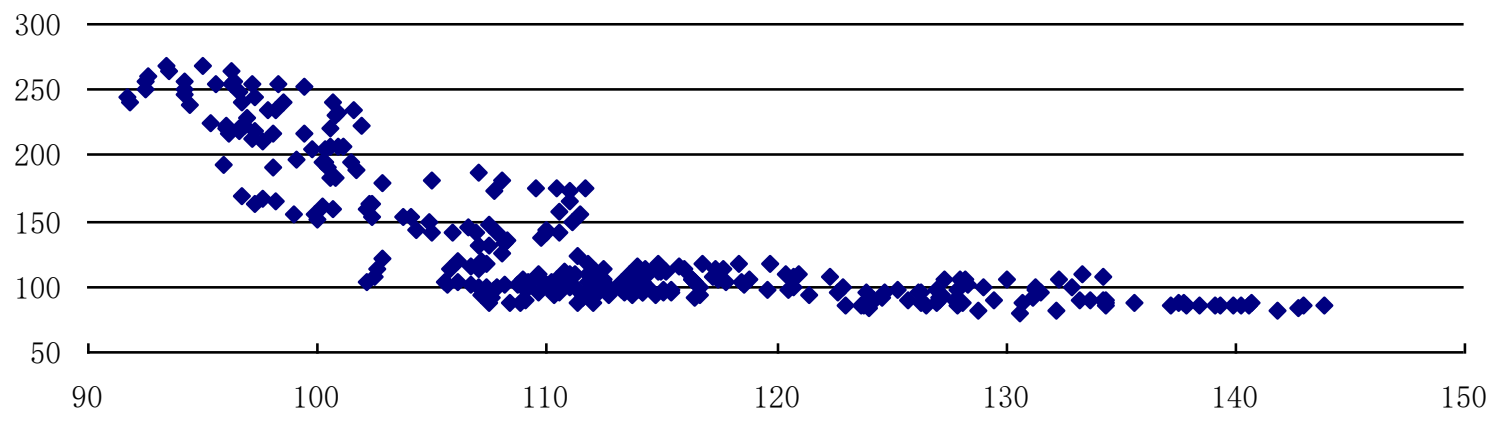

Figure 4. Dollar nominal effective exchange rate index scatter plot and cereal prices ${ }^{4}$

\section{Econometric Construction and Analysis}

From the above analysis, it can be known that agricultural productivity, food production, consumption, inventory, world oil prices, the dollar exchange rate and so on are important factors affecting the world food prices, but the significance and the degree of these factors upon world food prices need to be analyzed through econometric model.

First of all, choosing the proper variables and making an analysis. As stated earlier, the food in this paper refers to the food in its narrow sense, namely, grain, so the grain price data USES is grain prices. Due to the grain contains many kinds, so there can be no monetary unit to represent price. This paper uses the grain price index calculated by the United Nations food and agriculture organization. The agricultural productivity used to represent the production efficiency is calculated by the United States department of agriculture, agricultural total factor productivity (TFP). Food production,

\footnotetext{
${ }^{3}$ Data from the FAO (http://www.fao.org) database and British Petroleum (BP) World Energy Statistics Yearbook 2014 (http://www.bp.com/statisticalreview).

${ }^{4}$ Data from the FAO (http://www.fao.org) database and the Bank for International Settlements (http://www.bis.org) database.
} 
consumption and inventory are using the data aggregation of rice, wheat, corn, barley, rye, oats, sorghum, millet and grain variety stored in USDA food database, that is the grain output, consumption and inventory, and the inventory used is the beginning inventory.

The price of crude oil using bp world oil prices in the world's energy statistics yearbook 2014 and a calculation is made according to the value of the dollar in 2013. \$effective exchange rate using the bank for international settlements is Narrow in the database of the nominal effective exchange rate indices data. Considering the availability of each variable data, this article set sample interval is 1964-2013, 50 years of sample data. As the greenback's effective exchange rate is in statistics, need to convert them into annual data, this paper USES the method is the China statistical yearbook, when calculating the yuan's exchange rate is often used in the every twelve months a year of data for a simple arithmetic average. In addition, the annual data from 1990 world grain price index, but the United Nations food and agriculture organization (fao) statistics since 1961's food price index, is calculated by 2002 to 2004 as 100 . The food price index calculation in addition to including cereals include meat, milk, vegetables, cooking oil and sugar, etc., but the grain price fluctuations compared with other kind of food should be slightly lower, so the grain price index should be slightly below the food price index. Through calculation, 1990-2013, on average, the grain price index is 0.9759 times the food price index. Thus, in this paper, the food price index in 0.9759 by 1990 to adjust the coefficient of the grain price index are obtained. So you got all the required data, and food prices, production efficiency, food production, consumption, inventory, crude OIL prices and the dollar effective exchange rate respectively with PRI, TFP, PRO and CON, STO, OIL, investigate the said. Descriptive statistics data are summarized in Table 1.

Table 1. Descriptive statistics of relevant variables

\begin{tabular}{cccccccc}
\hline & PRI & TFP & PRO & CON & STO & EER & OIL \\
\hline Mean & 100.0002 & 76.5517 & 16.2998 & 16.1709 & 3.8709 & 125.6633 & 47.6994 \\
Median & 93.6550 & 71.2301 & 16.6832 & 16.5822 & 4.1865 & 124.8517 & 37.1500 \\
Maximum & 240.9318 & 105.4582 & 24.6400 & 23.9692 & 5.8761 & 165.8575 & 115.2200 \\
Min & 34.1318 & 62.7096 & 9.0461 & 8.9576 & 1.5914 & 94.2083 & 10.7900 \\
Standard deviation & 51.2395 & 13.2316 & 4.0353 & 4.0062 & 1.2921 & 17.7021 & 31.1202 \\
\hline
\end{tabular}

Note: PRO, CON, STO units of one hundred million tons, OIL is in US dollars / barrel. Other variables are indices.

In the time series data is applied to make the model, in order to avoid spurious regression, require stationary test. First of all take the natural logarithm of the original data processing, and then to pick up after the logarithmic variables of unit root test, using the ADF test. Inspection type in order to determine to do after taking the logarithm variable linear graph, we can find that, all variable intercept, and besides LN (investigate) have time trend. After the first order difference determination of inspection type also USES the same way. Lag order number is determined by the schwarz information criterion. Through the inspection results can be seen in table 2, each variable after taking logarithm are not smooth, but after the first order difference under the significance level of $1 \%$ by test. This suggests that cannot regression analysis, but can undertake cointegration test, if there is a cointegration relationship can build cointegration equation and error correction model. By Johansen cointegration test shows that under 5\% significance level, the characteristic root tracing test and the maximum characteristic value of test results show that there is one collaborators integral equation (a collaborators in as much as the whole equation under the null hypothesis of characteristic root tracing test statistic is 95.3854 , along with the probability $\mathrm{p}$ was 0.053 ; the maximum characteristic value of test statistics is 31.9828 , along with the probability p 0.3039). This showed that the trend of world food prices and other variables exist long-term relationship, cointegration equation was given through the type (1), the Numbers in parentheses are standard deviations. Through the coefficient and the ratio of the standard deviation can be calculated relevant variables t statistic, under 5\% significance level, LN (TFP), LN (PRO), LN (CON) and LN (investigate) coefficient is not zero, other coefficients were not significant. 
Table 2. Relevant variables unit root test

\begin{tabular}{lccccc}
\hline Variable & $\begin{array}{c}\text { Inspection Type } \\
(\mathrm{C}, \mathrm{T}, \mathrm{L})\end{array}$ & ADF value & Order Difference & $\begin{array}{c}\text { Inspection Type } \\
(\mathrm{C}, \mathrm{T}, \mathrm{L})\end{array}$ & ADF value \\
\hline$L N(P R I)$ & $(\mathrm{C}, \mathrm{T}, 0)$ & -1.8903 & $\Delta L N(P R I)$ & $(0,0,1)$ & $-5.3456^{* * *}$ \\
$L N(T F P)$ & $(\mathrm{C}, \mathrm{T}, 0)$ & -1.6283 & $\Delta L N(T F P)$ & $(\mathrm{C}, \mathrm{T}, 0)$ & $-5.3890^{* * *}$ \\
$L N(P R O)$ & $(\mathrm{C}, \mathrm{T}, 0)$ & -3.2610 & $\Delta L N(P R O)$ & $(0,0,0)$ & $-8.0777^{* * *}$ \\
$L N(C O N)$ & $(\mathrm{C}, \mathrm{T}, 0)$ & -2.7752 & $\Delta L N(C O N)$ & $(\mathrm{C}, 0,0)$ & $-6.8014^{* * *}$ \\
$L N(S T O)$ & $(\mathrm{C}, \mathrm{T}, 0)$ & -1.7006 & $\Delta L N(S T O)$ & $(\mathrm{C}, 0,0)$ & $-6.7776^{* * *}$ \\
$L N(O I L)$ & $(\mathrm{C}, \mathrm{T}, 0)$ & -1.6826 & $\Delta L N(O I L)$ & $(0,0,0)$ & $-6.7994^{* * *}$ \\
$L N(E E R)$ & $(\mathrm{C}, 0,1)$ & -2.2094 & $\Delta L N(E E R)$ & $(0,0,0)$ & $-4.3569^{* * *}$ \\
\hline
\end{tabular}

Note: The test type C, T, L, respectively, intercept, linear trend term and lag order, which lag order is chosen according to the number of Schwarz Information Criterion (SIC); *** denotes $1 \%$ significance level

$$
\begin{aligned}
L N(P R I)= & -2.4956 L N(T F P)-43.6415 L N(P R O)-0.3901 L N(S T O)+47.9617 L N(C O N) \\
& (0.8850) \quad(6.4327) \quad(0.3444) \\
& -0.7801 L N(E E R)-0.0908 L N(\text { OIL })+8.2997 \\
& (0.3762) \quad(0.0988)
\end{aligned}
$$

Through co-integration equation coefficient can be seen that world food prices by the agricultural total factor productivity significantly negative influence, the higher the total factor productivity of agriculture shows that grain production efficiency is higher, so food production unit of social necessary labor time is less, the value of the grain, the lower the result value of currency performance and the lower the price. LN (PRO) in front of the coefficient is negative, also shows that as the world's food production increase, world food prices will decline; LN (CON) in front of the coefficient is positive, that when the world's food consumption increases, the world food prices will rise. Is the world's food output and consumption coefficient, in front of the world food consumption coefficient absolute value is greater than the coefficient of absolute value in world food production, and this shows that when the world's food production and consumption are increased by $1 \%$, the world food prices will rise, and the changes in world food prices on world food production elasticity of elasticity is less than the world's food consumption change. Investigate its reason, may be the world's food consumption are more likely to change, more under the influence of related factors, and the world food production far short time is not easy to change, because the production of food depends on its own growth cycle, and changes in the production only after going through a growth cycle. The dollar's effective exchange rate coefficient is negative, it shows that when the dollar, the world food prices will fall. This is mainly because the world's food trade mainly is dollar-denominated; inevitably there are tradeoffs between relations. World grain stocks coefficient is negative, the results with the above analysis has been, namely food initial inventory, the more that food supply, the more so the price will be lower. But, the coefficients by significance test, the world grain stocks no significant impact on world food prices. Its reason mainly lies in world grain stocks relative to the food production and consumption has remained relatively stable level, itself changes little change, so the elastic was not significant. World oil prices impact on world food prices was not significant in statistics, and through the granger causality test as you can see, both are not the granger reason of the other party. The reason may be that the world food prices and the relationship between the prices of crude oil is mainly on the relationship between volatility rather than long-term trends. Cointegration equation reflects the long-term trend of relationship between variables, short-term adjustment of the relationship between variables requires the vector error correction model to analyze. But from the perspective of the results of error correction model, the statistical test of variable coefficients is not significant. This shows that only exist long-term trend relationships between variables, and no short-term adjustment.

\section{Conclusions and Enlightenment}

From what we have discussed above, we can draw the three conclusions as listed below.

First of all, the world food prices are affected by these four factors: agricultural productivity, the world's food production, consumption and the dollar's effective exchange rate. The higher the world agricultural productivity is, the lower the world food prices are. If the world food production is much higher, the world food prices will become lower. If the world food consumption is higher, the world food prices will be higher. And if dollar effective exchange rate is higher, the world food prices will be lower. Besides, the world food stocks and world oil prices also have an effect on the world food prices. But it's not very significant. 
Secondly, thechanges of world food prices about world food production is less than the change of the world's food consumption. This is associated with the variability of different food production and consumption. Obviously, consumption affected more easily than production.

Thirdly, there is a long-term trend between the world food prices and its correlated variables. However, there is no relationship of short - term adjustment. Therefore, the formation of world food prices is affected by many factors. Governments should take some effective measures to stable or reduce world food prices. When the current food prices is rising to impact the security of world food, especially in low-income country. Such as through strengthen support for agriculture development, especially the biological technology support to improve the efficiency of agricultural production and increase the world's food production. Through the world food consumption and the analysis of the dollar exchange rate fluctuations to anticipate the world food prices and takes measures to ensure food security early.

\section{References}

Baffes, J. (2011). The Economics of Food: How Feeding and Fueling the Planet Affects Food Prices. European Review of Agricultural Economics, 38(1), 157-160. https://doi.org/10.1093/erae/jbr001

Bigman, D., Goldfarb, D., \& Schechtman, E. (1983). Futures Market Efficiency and the time content of the information sets. Journal of Futures Markets, 3(3), 321-334. https://doi.org/10.1002/fut.3990030307

Christiaensen, L. (2009) Revisiting the Global Food Architecture. Lessons from the 2008 Food Crisis. Review of Business and Economics, (3), 3345-3361.

Cooke, B., \& Robles, M. (2009). Recent food price movements: a time series analysis. IFPRI Discussion Paper, Washington, DC.

Dai, J. P., \& Wang, W. B. (2009). International food prices and their output, consumption and inventory. International Trade Issues, 5, 35-40.

Gilbert, C., \& Morgan, W. (2010). Has food price volatility risen? Discussion Paper, Trento, Italy. https://doi.org/10.1007/978-1-4419-7634-5_4

Gilbert, C. (2011). International Agreements for Commodity Price Stabilization: An Assessment. OECD Food Agriculture and Fisheries Papers, 53.

Gilbert, C. L. (2006). Trends and volatility in agricultural commodity prices. In Sarris A. \& Hallam D eds. Agricultural commodity markets and trade $(31-60)$. Cheltenham, UK: Edward Elgar,

Gilbert, C. L. (2010). How to Understand High Food Prices. Journal of Agricultural Economics, 61(2), 398-425. https://doi.org/10.1111/j.1477-9552.2010.00248.x

Huang, J. K., Yang, J., Qiu, G. H., \& Xu, Z. G. (2009).The grain price change radically: the main causes and future trend. Management World, (1), 72-78.

Karali, B., \& Power, G. J. (2013). Short- and Long-Run Determinants of Commodity Price Volatility. American Journal of Agricultural Economics, 95(3), 724-738. https://doi.org/10.1093/ajae/aas122

Mitra, S., \& Boussard, J. M. A. (2012). Simple model of endogenous agricultural commodity price fluctuations with storage. Agricultural Economics, 43(1), 1-15. https://doi.org/10.1111/j.1574-0862.2011.00561.x

Nazlioglu, S., \& Soytas, U. (2011). World oil prices and agricultural commodity prices: Evidence from an emerging market. Energy Economics, 33(3), 488-496. https://doi.org/10.1016/j.eneco.2010.11.012

Pindyck, R. S. (1994). Inventories and the Short-Run Dynamics of Commodity Prices. RAND Journal of Economics, 25(1), 141-159. https://doi.org/10.2307/2555858

Smith, V. H., \& Lapp, J. S. (1993). Relative Price Variability Among Agricultural Commodities And Macroeconomic Instability In The United Kingdom. Journal of Agricultural Economics, 44(2), 272-283. https://doi.org/10.1111/j.1477-9552.1993.tb00271.x

Tyner, W., \& Taheripour, F. (2008). Biofuels, Policy Options, and Their Implications: Analyses Using Partial and General Equilibrium Approaches. Journal of Agricultural \& Food Industrial Organization, 6(2), 1-19.

https://doi.org/10.2202/1542-0485.1234

\section{Copyrights}

Copyright for this article is retained by the author(s), with first publication rights granted to the journal.

This is an open-access article distributed under the terms and conditions of the Creative Commons Attribution license which permits unrestricted use, distribution, and reproduction in any medium, provided the original work is properly cited. 